\title{
SPHERICAL AGGLOMERATION A NOVEL APPROACH FOR SOLUBILITY AND DISSOLUTION ENHANCEMENT OF SIMVASTATIN
}

\author{
PARMAR SHITAL S, MISHRA RAKESH*, SHIROLKAR SV
}

Department of Pharmaceutics, Dr. D.Y. Patil Institute of Pharmaceutical Sciences and Research, Pimpri, Pune, Maharashtra, India. Email: mishrarakesh287@gmail.com

Received: 11 June 2016, Revised and Accepted: 23 June 2016

\section{ABSTRACT}

Objective: Simvastatin is water insoluble drug commonly used in the treatment of hypercholesterolemia and dyslipidemia. The objective of the present investigation was to develop simvastatin spherical agglomerates to improve its solubility and dissolution characteristics by spherical agglomeration method.

Methods: In preparation of simvastatin spherical agglomerates crystallization media used were methanol, water, and chloroform as bridging liquid and PVP K-30 as a polymer. The process variables such as amount and type of (bridging liquid and polymer), stirring speed, and stirring time were optimized. The spherical agglomerates were characterized by suitable analytical techniques and further subjected for determination of \% drug content, particle shape analysis, solubility, and dissolution rate. The spherical agglomerates of the optimized batch were directly compressed into tablet; the dissolution profile of prepared tablet was compared with dissolution profile of marketed tablet.

Result: The spherical agglomerates obtained with methanol (7 ml), water (50 ml), chloroform (1.5 ml), and PVP K-30 (0.5\%) at $500 \mathrm{rpm}$ and 15 minutes stirring time showed significant improvement in solubility and dissolution from a value of $0.029 \mathrm{mg} / \mathrm{ml}$ and $25.53 \%$ for pure simvastatin to $6.42 \mathrm{mg} / \mathrm{ml}$ and $91.31 \%$ of spherical agglomerate, respectively. The simvastatin tablet obtained with spherical agglomerates showed $89.65 \%$ cumulative drug release as compare to $80.28 \%$ of marketed tablet.

Conclusion: A significant result obtained with the study indicates that spherical crystallization by spherical agglomeration technique can successfully be further explored and employed to improve solubility and dissolution characteristic of poorly soluble drugs.

Keywords: Simvastatin, Spherical agglomeration, Solubility, Dissolution.

(C) 2016 The Authors. Published by Innovare Academic Sciences Pvt Ltd. This is an open access article under the CC BY license (http://creativecommons. org/licenses/by/4. 0/) DOI: http://dx.doi.org/10.22159/ajpcr.2016.v9i6.13420

\section{INTRODUCTION}

Spherical crystallization is the novel agglomeration technique that can transform directly the fine crystals produced in the crystallization process into a spherical shape. It is the particle engineering technique by which crystallization and agglomeration can be carried out simultaneously in one step to transform crystals directly into compacted spherical form and which has been successfully utilized for improvement of solubility and dissolution [1].

Poor physical and mechanical properties of drug particles have been masked by various wet granulation methods, such as high-shear and fluid bed wet granulation, which generally involve mixing, atomization, and spraying of granulation liquid on powders, drying steps, sieving, and so on. Both agglomeration methods are an energy-consuming process. Other agglomeration techniques, such as dry granulation, hot melt granulation, melt extrusion, spray congealing, or melt solidification have been introduced in recent years, and have yielded some innovative solutions for improving the physical and mechanical properties of drug particles; however, they are still less economical than direct compression tableting. Spherical agglomeration is the most commonly used method and involves the use of polymer and/or bridging liquids to simultaneously crystallize and agglomerate. Spherical agglomeration technique improves flow property and compression characteristics of the drug which can be directly compressed into tablet. A number of drugs such as salicylic acid, naproxen, celecoxib, ibuprofen, mefenamic acid, and nabumetone are reported in literature that has been processed using spherical agglomeration technique [2].

In this study, simvastatin was chosen as the model drug for spherical agglomeration. Simvastatin, a biopharmaceutics classification system class II drug, is a lipid-lowering agent that is derived synthetically from the fermentation of Aspergillus terreus $[3,4]$. It is a potent competitive inhibitor of 3-hydroxy-3-methylglutaryl coenzyme A reductase which is the rate-limiting enzyme in cholesterol biosynthesis $[5,6]$.

Micronization process gives rise to increased free surface energy and thus poor flowability and compressibility of powders which makes them difficult to use in downstream processing in the pharmaceutical industry such as direct tablet-making or capsule-filling processes. Therefore, this study involved optimization of spherical agglomeration aimed at improving the physico-technical properties, solubility, and dissolution characteristic of simvastatin.

\section{MATERIALS AND METHODS}

\section{Materials}

Simvastatin was gifted from Watson India Ambernath, Mumbai and Cipla Pvt. Ltd. PVP K-30 and hydroxypropyl methylcellulose were obtained from Colorcon Asia, (Goa). The other reagents and solvents were of analytical grade purchased from Universal Labs, Mumbai.

\section{Methods}

Preparation of spherical agglomerates by using different bridging liquid

The spherical crystal is obtained through spherical agglomeration technique. Nine batches were prepared depending on the change in concentration and type of bridging liquid (Table 1). Simvastatin was dissolved in methanol and poured in water followed by addition of bridging liquid (dichloromethane/chloroform/methanol) dropwise with different stirring speed and stirring time. The obtained precipitated agglomerates of simvastatin were dried for $24 \mathrm{hrs}$ at room temperature. 
Preparation of spherical agglomerates using chloroform as bridging liquid with polymers

The spherical crystal is obtained through spherical agglomeration technique. Six batches (B10 to B15) were prepared depending on the change in concentration and type of polymers (Table 2). Simvastatin was dissolved in methanol and poured in the mixture of water and polymer followed by addition of bridging liquid (chloroform) dropwise with different stirring speed and stirring time. The obtained precipitated agglomerates of simvastatin were dried for $24 \mathrm{hrs}$ at room temperature to enlarge the size of the agglomerates $[7,8]$. Further six batches (B16 to B21) were prepared to optimize stirring speed and time (Table 2).

\section{Preparation of tablet with optimized spherical agglomerates}

The tablets were prepared by using direct compression method. The powder ingredients, i.e., optimized spherical agglomerates and excipients, viz., microcrystalline cellulose, talc and magnesium stearate were weighed and mixed thoroughly to prepare homogeneous mixture. The homogeneous mass was compressed in tablet compression machine (Company: Karnavati; Model: Mini press II MT) using punch size $4 \mathrm{~mm}$ to obtain tablets of uniform size and shape (Table 3 ).

The optimized spherical agglomerates of simvastatin directly compressed and compared for percent cumulative drug release with a marketed tablet.

\section{Evaluation of optimized spherical agglomerates}

Optical microscopy

The external morphology of spherical agglomerates was studied by optical microscopy. The sample was taken on the glass slide and is observed under $10 \times, 45 \times$ and $100 \times$ magnifications [9].

\section{Flowability}

Both loose bulk density (LBD) and tapped bulk density (TBD) were determined. A quantity of $5 \mathrm{~g}$ of agglomerates was lightly shaken to break any agglomerates formed and then was introduced into a $100 \mathrm{ml}$ measuring cylinder. It was allowed to fall under its own weight onto a hard surface from the height of $2.5 \mathrm{~cm}$ at 2 second intervals.

The tapping was continued until no further change in volume was noted. LBD and TBD were calculated using the following formulae:

$$
\begin{aligned}
& \mathrm{LBD}=\frac{\text { Weight of the powder }}{\text { looseVolume of the powder bed }} \\
& \mathrm{TBD}=\frac{\text { Weight of the powder }}{\text { Tapped Volume of the powder bed }}
\end{aligned}
$$

The compressibility indices of the formulation blend were determined through Carr's compressibility index:

Carr's Compressibility Index $(\%)=\frac{\text { TBD }- \text { LBD }}{\text { TBD }} \times 100$

From the mass and occupied volume respective densities were calculate, from these densities the density ratio (Hausner's ratio) calculated:

$$
\text { HR }=\frac{\text { Tapped Density }}{\text { Bulk Density }}
$$

Values $<1.25$ indicate good flow (20\% Carr index.) and the value $<1.25$

\begin{tabular}{|c|c|c|c|c|c|c|c|c|c|}
\hline \multirow{2}{*}{$\begin{array}{l}\text { Batch } \\
\text { number }\end{array}$} & \multirow{2}{*}{$\begin{array}{l}\text { Simvastatin } \\
\text { (mg) }\end{array}$} & \multirow{2}{*}{$\begin{array}{l}\text { Goodsolvent } \\
\text { (ml) }\end{array}$} & \multirow{2}{*}{$\begin{array}{l}\text { BadSolvent } \\
\text { (ml) (Water) }\end{array}$} & \multicolumn{3}{|c|}{ Bridging liquid (ml) } & \multirow{2}{*}{$\begin{array}{l}\text { Stirringspeed } \\
\text { (Rpm) }\end{array}$} & \multirow{2}{*}{$\begin{array}{l}\text { Stirringtime } \\
\text { (minutes) }\end{array}$} & \multirow{2}{*}{$\begin{array}{l}\text { Weight of } \\
\text { agglomerates } \\
\text { obtained (mg) }\end{array}$} \\
\hline & & & & Chloroform & DCM & Methanol & & & \\
\hline B1 & 500 & 5 & 10 & 1 & - & - & 300 & 20 & 86.1 \\
\hline B2 & 500 & 5 & 10 & 1.5 & - & - & 700 & 15 & 64.4 \\
\hline B3 & 500 & 5 & 50 & 1.2 & - & - & 1000 & 20 & 52.2 \\
\hline B4 & 500 & 5 & 50 & - & 2 & - & 500 & 15 & 275.6 \\
\hline B5 & 500 & 5 & 50 & - & - & 2 & 500 & 15 & 325.4 \\
\hline B6 & 500 & 5 & 50 & 2 & - & - & 500 & 15 & 486.1 \\
\hline B7 & 500 & 5 & 50 & 1 & - & - & 500 & 15 & 405.2 \\
\hline B8 & 500 & 5 & 50 & 1.5 & - & - & 500 & 15 & 375.9 \\
\hline B9 & 500 & 5 & 50 & 2 & - & - & 500 & 15 & 301.4 \\
\hline
\end{tabular}
indicates poor flow (33\% Carr index.) $[10,11]$.

Table 1: Formulation of spherical agglomerates prepared with different bridging liquid

\begin{tabular}{|c|c|c|c|c|c|c|c|c|c|}
\hline \multirow[t]{2}{*}{$\begin{array}{l}\text { Batch } \\
\text { number }\end{array}$} & \multirow[t]{2}{*}{$\begin{array}{l}\text { Simvastatin } \\
\text { (mg) }\end{array}$} & \multirow[t]{2}{*}{$\begin{array}{l}\text { Good solvent } \\
\text { (ml) methanol }\end{array}$} & \multirow{2}{*}{$\begin{array}{l}\text { Bad solvent } \\
(\mathrm{ml}) \\
\text { (distilled } \\
\text { water) }\end{array}$} & \multirow{2}{*}{$\begin{array}{l}\text { Bridging liquid } \\
\text { (ml) } \\
\text { (chloroform) }\end{array}$} & \multicolumn{2}{|c|}{$\begin{array}{l}\text { Polymer with } \\
\text { conc. }\end{array}$} & \multirow{2}{*}{$\begin{array}{l}\text { Stirring } \\
\text { speed } \\
\text { (Rpm) }\end{array}$} & \multirow[t]{2}{*}{$\begin{array}{l}\text { Stirringtime } \\
\text { (minutes) }\end{array}$} & \multirow{2}{*}{$\begin{array}{l}\text { Weight of } \\
\text { agglomerates } \\
\text { obtained (mg) }\end{array}$} \\
\hline & & & & & $\begin{array}{l}\text { PVPK-30 } \\
(\%)\end{array}$ & $\begin{array}{l}\text { HPMC } \\
(\%)\end{array}$ & & & \\
\hline B10 & 500 & 7 & 50 & 1.5 & 0.5 & - & 500 & 15 & 415.3 \\
\hline B11 & 500 & 7 & 50 & 1.5 & - & 0.5 & 500 & 15 & 376.1 \\
\hline B12 & 500 & 7 & 50 & 1.5 & 0.25 & 0.25 & 500 & 15 & 215.9 \\
\hline B14 & 500 & 5 & 50 & 1.5 & 0.5 & - & 500 & 15 & 401.8 \\
\hline B15 & 500 & 5 & 50 & 1.5 & 0.25 & - & 500 & 15 & 435.9 \\
\hline B16 & 500 & 5 & 50 & 1.5 & 0.5 & - & 750 & 15 & 379.9 \\
\hline B17 & 500 & 5 & 50 & 1.5 & 0.5 & - & 500 & 15 & 308.7 \\
\hline B18 & 500 & 5 & 50 & 1.5 & 0.5 & - & 250 & 15 & 391.5 \\
\hline B19 & 1000 & 7 & 50 & 1.5 & 0.5 & - & 500 & 05 & 654.3 \\
\hline B20 & 1000 & 7 & 50 & 1.5 & 0.5 & - & 500 & 15 & 752.4 \\
\hline B21 & 1000 & 7 & 50 & 1.5 & 0.5 & - & 500 & 30 & 836.9 \\
\hline
\end{tabular}

DCM: Dichloromethane

Table 2: Formulation of spherical agglomerates by using chloroform as bridging liquid with polymers

HPMC: Hydroxypropyl methylcellulose 


\section{Percent drug content}

The optimized formulation was triturated in mortar and pestle. Powder equivalent to a dose of simvastatin was weighed and dispersed into $100 \mathrm{ml}$ of methanol and sonicated using an ultrasonicator for 20 minutes. The resultant solution was filtered through Whatman filter paper No. 41, and a drug content was spectrophotometrically determined at $238 \mathrm{~nm}$ (model- ultraviolet (UV) 1700 Shimadzu, Japan).

\section{Solubility analysis}

The optimized formulation was mixed with $2 \mathrm{ml}$ of water to make saturated solution of simvastatin. The solution was placed inside orbital shaker for $48 \mathrm{hrs}$ followed by centrifugation in laboratory centrifuge at $300 \mathrm{rpm}$ for 15 minutes. The resultant solution was then filtered through Whatman filter paper No. 41 and further diluted with distilled water. Solubility was spectrophotometrically determined at $238 \mathrm{~nm}$ (model-UV 1700 Shimadzu, Japan) [12,13].

\section{Dissolution studies}

Drug release studies of prepared agglomerates were performed by USP dissolution apparatus 2 (DT 60, Veego Instruments) with $900 \mathrm{ml}$ of phosphate buffer pH-7.0 as dissolution medium at $37 \pm 0.1^{\circ} \mathrm{C}$. The speed of the paddle was adjusted to $50 \mathrm{rpm}$. The prepared agglomerates were packed inside muslin cloth and tied to the paddle. An aliquot of $1 \mathrm{ml}$ was collected at an interval of 10 minutes and diluted with Phosphate buffer pH-7.0 up to $10 \mathrm{ml}$ then, analyzed for the content of simvastatin by UV-spectrophotometer at $238 \mathrm{~nm}$. An equivalent volume $(1 \mathrm{ml})$ of fresh dissolution medium was added to compensate for the loss due $[14,15]$.

\section{Differential scanning calorimeter (DSC)}

DSC spectra of pure drug and spherical agglomerates were carried out using DSC equipment.

\section{Powder X-ray powder diffraction}

Powder X-ray diffraction (PXRD) patterns were carried out by $\mathrm{X}$-ray diffractometer for the samples. The samples were analyzed at 1 minutes/second over the 1-50 diffraction angle $(2 \theta)$ range.

Evaluation of formulated tablets prepared with optimized spherical agglomerates [16,17]

Dissolution studies

Drug release studies of formulated tablets were performed by USP dissolution apparatus 2 (DT 60, Veego Instruments) was used with $900 \mathrm{ml}$ of phosphate buffer pH-7.0 as dissolution medium at $37 \pm 0.1^{\circ} \mathrm{C}$. The speed of the paddle was adjusted to $50 \mathrm{rpm}$.

\section{Friability}

Friability testing of the tablets is carried out by roche friabilator. 20 tablets are placed inside of rotating drum which rotates at $25 \mathrm{rpm}$. The timer is set for 4 minutes to complete 100 rotations. The tablets are removed and \% weight loss is calculated.

\section{Hardness}

Hardness testing of the tablets is carried out by Monsanto hardness tester.

Table 3: Formulation of spherical agglomerate tablet(For 20 tablets)

\begin{tabular}{ll}
\hline Ingredient & Quantity (mg/20 tablet) \\
\hline Drug (simvastatin) & 200 \\
Talc & 150 \\
Magnesium stearate & 75 \\
PVP K-30 & 75 \\
Microcrystalline cellulose & Q.S. $700 \mathrm{mg}$ \\
\hline
\end{tabular}

\section{RESULTS AND DISCUSSION}

Calibration curve for simvastatin in distilled water

$10 \mathrm{mg}$ of simvastatin was dissolved in $100 \mathrm{ml}$ distilled water with $0.5 \%$ of sodium lauryl sulfate in $100 \mathrm{ml}$ volumetric flask to get $100 \mu \mathrm{g} / \mathrm{ml}$. UV spectrum was recorded in the wavelength range $200-400 \mathrm{~nm}$. A standard calibration curve was prepared for the concentration of $2-16 \mu \mathrm{g} / \mathrm{ml}$ at $238 \mathrm{~nm}$ (Fig. 1). The UV absorbance data at $238 \mathrm{~nm}$ and concentration estimates of pure simvastatin at this wavelength showed good linearity $\left(\mathrm{R}^{2}-0.983\right)$ over the concentration range of $2-16 \mu \mathrm{g} / \mathrm{ml}$.

Calibration curve for simvastatin in phosphate buffer $\mathrm{pH}-\mathbf{7 . 0}$

A amount of $10 \mathrm{mg}$ of simvastatin was dissolved in $100 \mathrm{ml}$ phosphate buffer pH-7.0 in $100 \mathrm{ml}$ volumetric flask to get $100 \mu \mathrm{g} / \mathrm{ml}$. UV spectrums were recorded in the wavelength range $200-400 \mathrm{~nm}$. A standard calibration curve was prepared for concentration from $2 \mu \mathrm{g} / \mathrm{ml}$ to $16 \mu \mathrm{g} / \mathrm{ml}$ at $238 \mathrm{~nm}$ (Fig. 2). The UV absorbance data at $238 \mathrm{~nm}$ and concentration estimates of pure simvastatin at this wavelength showed good linearity $\left(\mathrm{R}^{2}-0.9953\right)$ over the concentration range of $1-16 \mu \mathrm{g} / \mathrm{ml}$.

\section{Fourier transform infrared spectroscopy spectroscopy}

About $0.1 \mathrm{~g}$ of simvastatin was mixed and triturated with dry potassium bromide. This mixture was placed in DRS assembly sample holder. The infrared spectrum was recorded (Fig. 3) and the spectral analysis was done.

Morphological analysis of simvastatin by optical microscopy The optical microscopic images of the simvastatin show the needle-like particles (Fig. 4).

\section{Optimization of spherical agglomerates}

Optimization of bridging liquid

Nine Batches were prepared as given in (Table 1). In batches B-1, B-2, and B-3 spherical agglomerates were not obtained. After which batches were taken with the increase amount of bad solvent at different stirring speed and stirring time. The microscopic study showed agglomerates formation was more if chloroform was used as a bridging liquid (B6) as

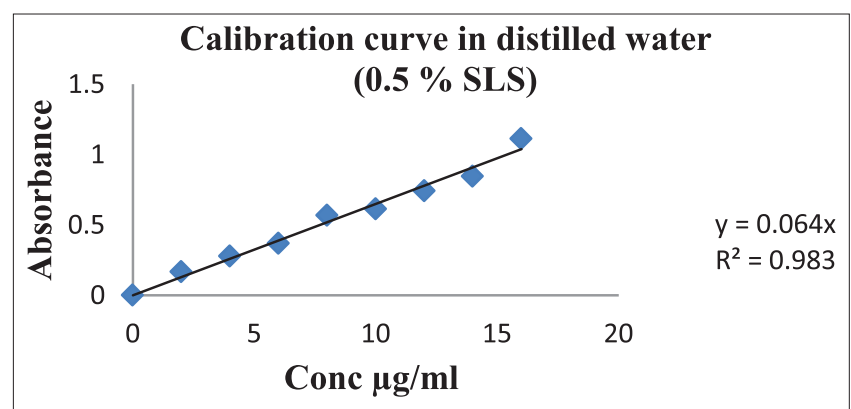

Fig. 1: Calibration curve of simvastatin in water $(0.5 \%$ sodium lauryl sulfate)

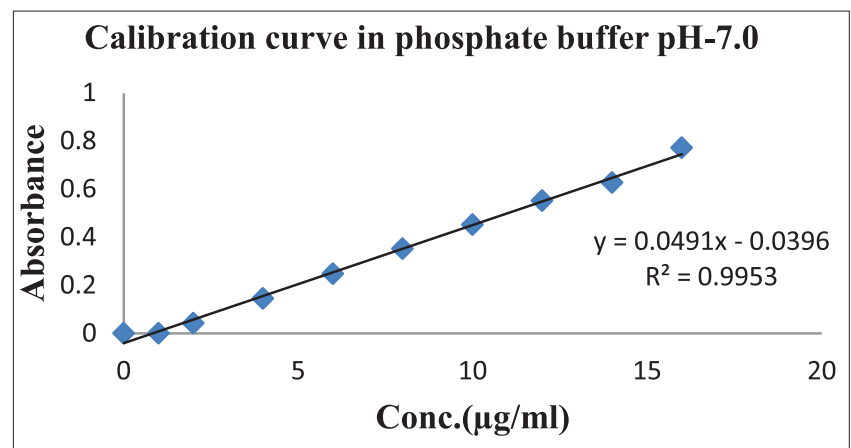

Fig. 2: Standard calibration curve of simvastatin in phosphate buffer pH-7.0 


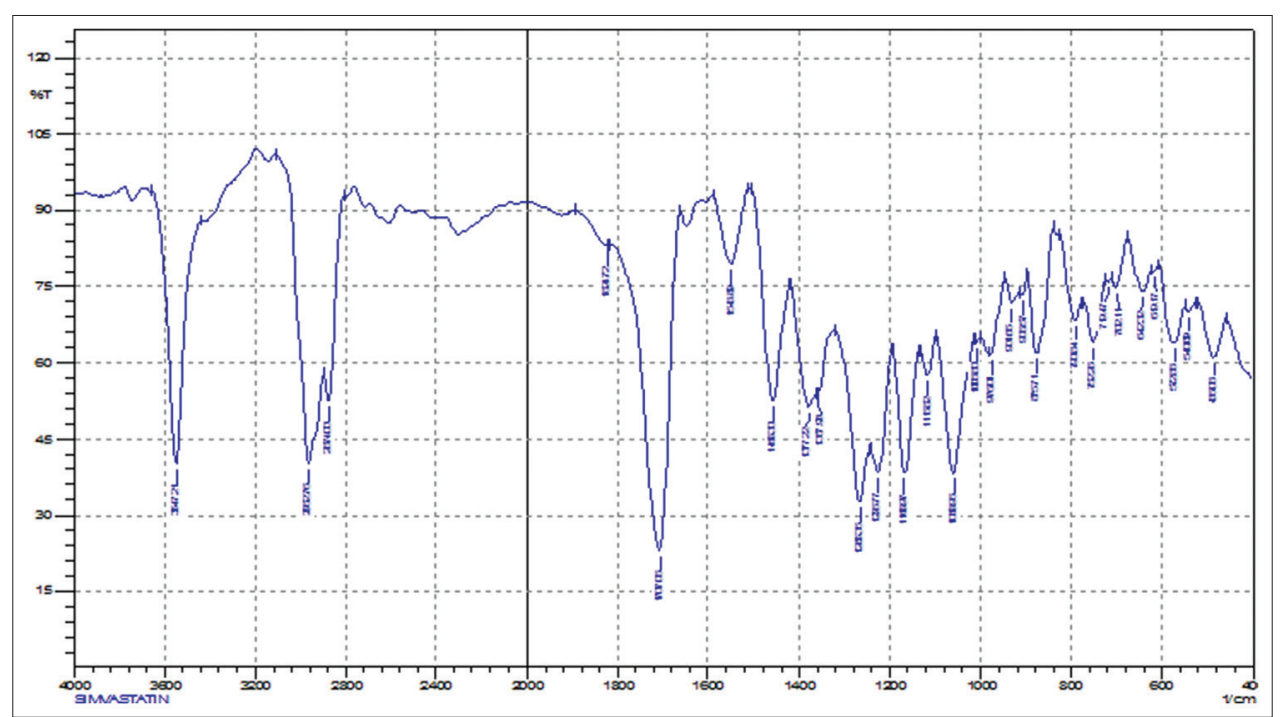

Fig. 3: Fourier transform infrared spectroscopy spectrum of simvastatin

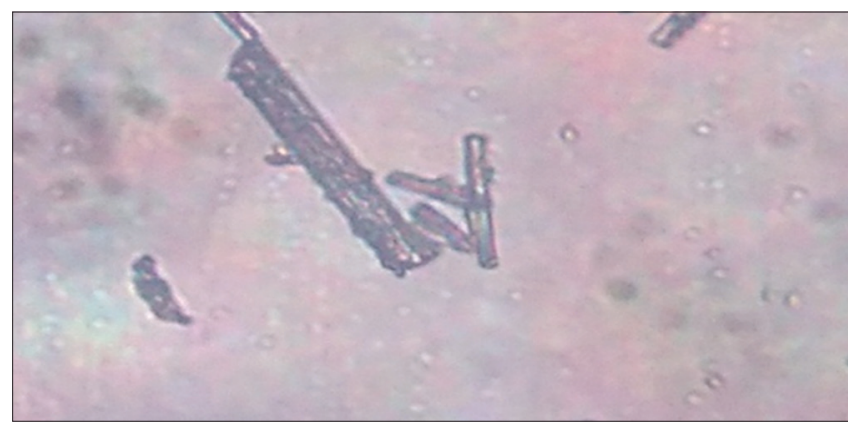

Fig. 4: Optical microscopy of pure drug simvastatin

compared to dichloromethane (Fig. 5). Further batches were prepared using chloroform as bridging liquid to optimize the concentration of chloroform. The shape of the agglomerates was more spherical in (B 8) batch obtained with chloroform (1.5 ml) as bridging liquid (Fig. 6).

\section{Optimization of polymer}

To study the effects of polymer on spherical agglomerates further batches (B10-B15) were prepared by using chloroform $(1.5 \mathrm{ml})$ as bridging liquid with the different polymer (PVP K-30 and hydroxypropyl methylcellulose [HPMC]). The microscopic study showed that the batches which were prepared by PVP K-30 (B10) will lead to a large number of agglomerates formations which were bigger in size and have spherical shape (Fig. 7). Further batches were prepared to optimize the concentration of PVP K-30, batch (B 14) gave better agglomerates which were more spherical in shape using 0.5\% PVP K-30 as compare to other batches (Fig. 8).

\section{Optimization of stirring speed (rpm)}

Further batches (B16-B18) were prepared by using chloroform $(1.5 \mathrm{ml})$ as bridging liquid and PVP K-30 (0.5\%) to optimize the stirring speed. The microscopic study showed batch (B17) prepared through $500 \mathrm{rpm}$ produced agglomerates which were ideal in size and were spherical in shape. Whereas, there was destruction of agglomerates into smaller agglomerates and formation of incomplete agglomerates in the case of batches which were prepared at $750 \mathrm{rpm}$ and $250 \mathrm{rpm}$, respectively (Fig. 9). Hence, the optimum speed was $500 \mathrm{rpm}$.

\section{Optimization of stirring time (minutes)}

Batches (B19-B21) were prepared using chloroform $(1.5 \mathrm{ml})$ as bridging liquid and PVP K-30 (0.5\%) at $500 \mathrm{rpm}$ to optimize the stirring time. The microscopic study showed that batch stirred for 30 minutes lead to destruction of agglomerates and batch stirred for 5 minutes gave incomplete agglomerates. Whereas, batch (B20) prepared with stirring 15 minutes for gave spherical agglomerates with optimal size and shape (Fig. 10).

\section{Solubility analysis}

The batch B6, B8, B10, B14, B17, and B20 showed suitable spherical agglomeration with optimum particle size and more spherical shape. Hence, these batches are subjected to solubility analysis to determine the change in solubility of simvastatin spherical agglomerates in comparison to pure simvastatin. Solubility profile shows that the solubility of batches prepared by spherical agglomeration is more than the solubility of pure drug (Fig. 11). The batches prepared with use of polymers shows higher solubility as compared to batches prepared with only organic solvent as bridging liquid. Thus, batches (B 14, B17 and B20) are subjected to dissolution testing.

\section{Dissolution profile}

Batch B20 provided the higher percentage cumulative release of $91.31 \%$ as compared to other batches and pure simvastatin (Fig. 12).

\section{DSC}

The DSC patterns of pure simvastatin and spherical agglomerates are shown in Fig. 13. Pure simvastatin showed a sharp endotherm at $141.1^{\circ} \mathrm{C}$ corresponding to its melting point. There was a slight change in the melting endotherm of the prepared spherical agglomerate compared to pure drug $140.6^{\circ} \mathrm{C}$.

\section{$X$-ray powder diffraction}

The results of the PXRD pattern of pure drug and spherical agglomerates are shown in (Figs. 14 and 15). Pure drug and the spherical agglomerate showed the same peaks, but the peak intensity was different. Thus, this indicates decrease in the crystallinity of spherical agglomerates compared to pure drug. Since all XRD peaks of the spherical agglomerates were consistent with the pattern of original drug crystals.

\section{Pre-compression assessment of optimized spherical} agglomerates

Spherical agglomerates were evaluated for its flow properties, porosity, and drug content; the results were found within the range (Table 4). 


\begin{tabular}{llll}
\hline Optical Microscopic Image & B04 & B06 & \\
& & & B05 \\
& & Methanol & Chloroform \\
\hline Bridging Liquid & Dichloromethane & 500 rpm & 500 rpm \\
Stirring Speed & 500rpm & 15 minutes & 15 minutes \\
Stirring Time & 15 minutes &
\end{tabular}

Fig. 5: Optimization of bridging liquid

\begin{tabular}{llll}
\hline Optical microscopic image & B07 & B08 & B09 \\
& & & \\
& & & \\
\hline Bridging liquid & Chloroform $(1 \mathrm{ml})$ & Chloroform $(1.5 \mathrm{ml})$ & Chloroform $(2 \mathrm{ml})$ \\
Stirring speed & $500 \mathrm{rpm}$ & $500 \mathrm{rpm}$ & $500 \mathrm{rpm}$ \\
Stirring time & 15 minutes & 15 minutes & 15 minutes \\
\hline
\end{tabular}

Fig. 6: Optimization of bridging liquid concentration

\begin{tabular}{|c|c|c|c|}
\hline Optical Microscopic Image & B10 & B11 & B12 \\
\hline Bridging liquid & Chloroform & Chloroform & Chloroform \\
\hline Stirring speed & $500 \mathrm{rpm}$ & $500 \mathrm{rpm}$ & $500 \mathrm{rpm}$ \\
\hline Stirring time & 15 minutes & 15 minutes & 15 minutes \\
\hline Polymer & 05\% PVP K-30 & $\begin{array}{l}0.5 \% \text { hydroxypropyl } \\
\text { methylcellulose }\end{array}$ & $\begin{array}{l}0.25 \% \text { PVP K- } 30+ \\
0.25 \% \text { HOMC }\end{array}$ \\
\hline
\end{tabular}

Fig. 7: Optimization of polymer

\begin{tabular}{|c|c|c|c|}
\hline Optical Microscopic Image & B13 & B14 & B15 \\
\hline Bridging liquid & Chloroform & Chloroform & Chloroform \\
\hline Stirring speed & $500 \mathrm{rpm}$ & $500 \mathrm{rpm}$ & $500 \mathrm{rpm}$ \\
\hline Stirring time & 15 minutes & 15 minutes & 15 minutes \\
\hline Polymer & $0.15 \%$ PVP K-30 & $0.5 \%$ PVP K-30 & $0.25 \%$ PVP K-30 \\
\hline
\end{tabular}

Fig. 8: Optimization of polymer concentration

Table 4: Pre-compression assessments of simvastatin spherical agglomerates

\begin{tabular}{lllllll}
\hline Formulation (batch) & $\begin{array}{l}\text { Granuledensity* } \\
\left(\mathbf{g} / \mathbf{c m}^{3}\right)\end{array}$ & $\begin{array}{l}\text { Tapped density* } \\
\left(\mathbf{g} / \mathbf{c m}^{\mathbf{3}}\right)\end{array}$ & $\begin{array}{l}\text { Hausner's } \\
\text { ratio* }\end{array}$ & $\begin{array}{l}\text { Carrs } \\
\text { index* }\end{array}$ & Drug content (\%) & Porosity* \\
\hline B20-1 & $0.30 \pm 0.02$ & $0.34 \pm 0.036$ & $1.13 \pm 0.033$ & $12.01 \pm 2.43$ & $97.69 \pm 0.23$ & $2.026 \pm 0.23$ \\
\hline${ }^{*} \mathrm{Mean} \pm \mathrm{SD}(\mathrm{n}=3)$. SD: Standard deviation & & & & &
\end{tabular}




\begin{tabular}{lllc}
\hline Optical Microscopic Image & B16 & B17 & B18 \\
& & & \\
& & Chloroform & Chloroform \\
\hline Bridging liquid & Chloroform & 500 rpm & 250 rpm \\
Stirring speed & 750 rpm & 15 minutes & 15 minutes \\
Stirring time & 15 minutes & $0.5 \%$ PVP K-30 & $0.5 \%$ PVP K-30 \\
Polymer & $0.5 \%$ PVP K-30 & & \\
\hline
\end{tabular}

Fig. 9: Optimization of stirring speed (rpm)

\begin{tabular}{lllc}
\hline Optical Microscopic Image & B19 & B20 & B21 \\
& & & \\
& & Chloroform & Chloroform \\
Bridging liquid & Chloroform & 500 rpm & $500 \mathrm{rpm}$ \\
Stirring speed & 500 rpm & 15 minutes & 30 minutes \\
Stirring time & 05 minutes & $0.5 \%$ PVP K-30 & $0.5 \%$ PVP K-30 \\
Polymer & $0.5 \%$ PVP K-30 & \\
\hline
\end{tabular}

Fig. 10: Optimization of stirring time (minute)

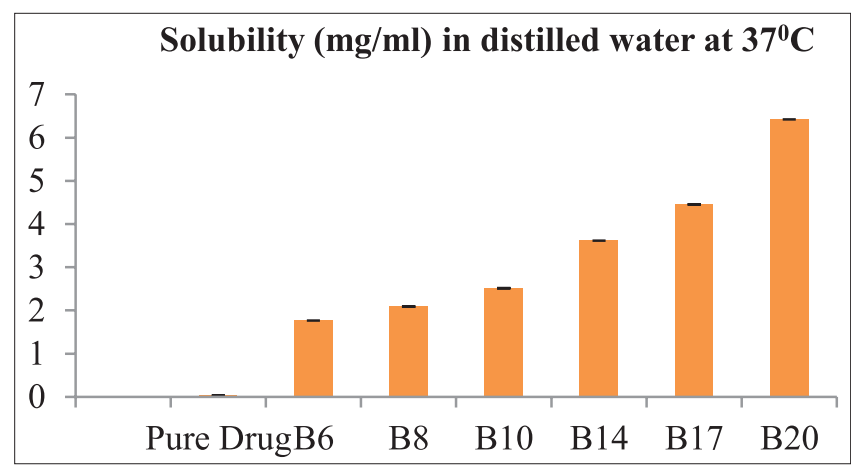

Fig. 11: Solubility profile of obtained formulations and pure drug. Mean \pm standard deviation $(n=3)$

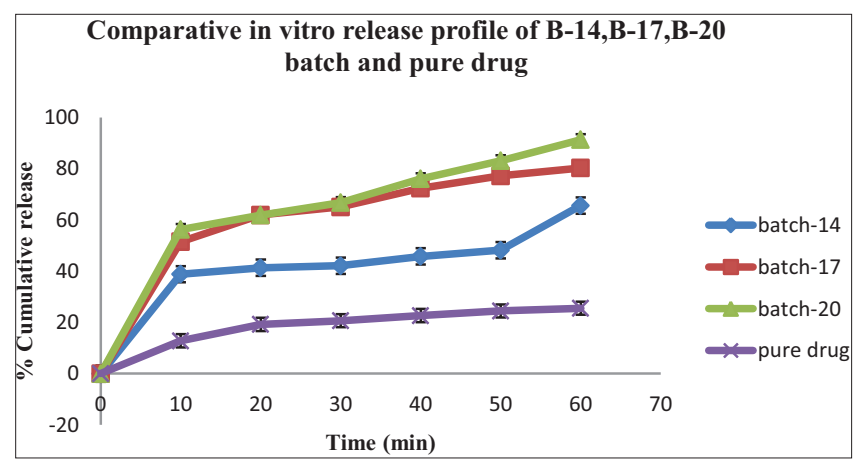

Fig. 12: Comparison of in-vitro release profile of optimized batches and pure drug. Mean \pm standard deviation $(n=3)$

Post-compression assessment of simvastatin tablets prepared with batch (B-20) spherical agglomerates

Spherical agglomerate obtained in B20 batch was compressed to obtain $10 \mathrm{mg}$ tablet and evaluated for physiochemical properties and dissolution studies (Table 5).
Table 5: Physical evaluation of spherical agglomerates tablets

\begin{tabular}{llcl}
\hline $\begin{array}{l}\text { Formulation } \\
\text { code }\end{array}$ & $\begin{array}{l}\text { Friability* } \\
\text { (\%) }\end{array}$ & $\begin{array}{l}\text { Hardness* } \\
\left(\mathbf{K g} / \mathbf{c m}^{2}\right)\end{array}$ & $\begin{array}{l}\text { Drug content } \\
\text { (\%) }\end{array}$ \\
\hline B20-T & $0.460 \pm 0.005$ & $5.83 \pm 0.41$ & $98.01 \pm 0.28$ \\
\hline
\end{tabular}

${ }^{*}$ Mean \pm SD (n=3). SD: Standard deviation

Dissolution profile comparison between formulated tablet and marketed tablet

Marketed tablet of simvastatin-10 mg (Simcard) were purchased, and comparative dissolution profile was generated for tablet prepared with B20 batch. The formulated tablet of simvastatin and marketed tablet was found to show $89.65 \%$ and $80.28 \%$ cumulative release, respectively (Fig. 16).

\section{CONCLUSION}

The spherical agglomerate of poorly water soluble drug simvastatin was prepared to improve the solubility and dissolution characterize. The (infrared and UV spectroscopy were carried out for identification of the said drug and purity was affirmed. The spherical agglomerates obtained with methanol as a good solvent of $7.0 \mathrm{ml}$, distill water as a bad solvent of $50 \mathrm{ml}$ with $0.5 \%$ PVP K-30 and chloroform as a bridging liquid of $1.5 \mathrm{ml}$; at a stirring rate of $500 \mathrm{rpm}$ and stirring time of 15 minutes was best suited to obtain the spherical agglomerates with better processability. The obtained agglomerates also showed improved solubility and dissolution compared to pure simvastatin. The solubility profile of the spherical agglomerates was found to be in between $1.764 \mathrm{mg} / \mathrm{ml}$ and $6.42 \mathrm{mg} / \mathrm{ml}$ which is more than that of pure drug, i.e., $0.029 \mathrm{mg} / \mathrm{ml}$ and dissolution profile was $91.31 \%$ of spherical agglomerate and $25.53 \%$ of the pure drug in phosphate buffer $\mathrm{pH}-7.0$. The percent drug release in phosphate buffer pH-7.0 at 60 minutes was found to be $89.65 \%$ and $80.28 \%$ of formulated and marketed tablet, respectively. Moreover, encouraging result of the present study further can be explored to generate ready-to-formulate API, thus saving on time and effort at the formulator's end. 


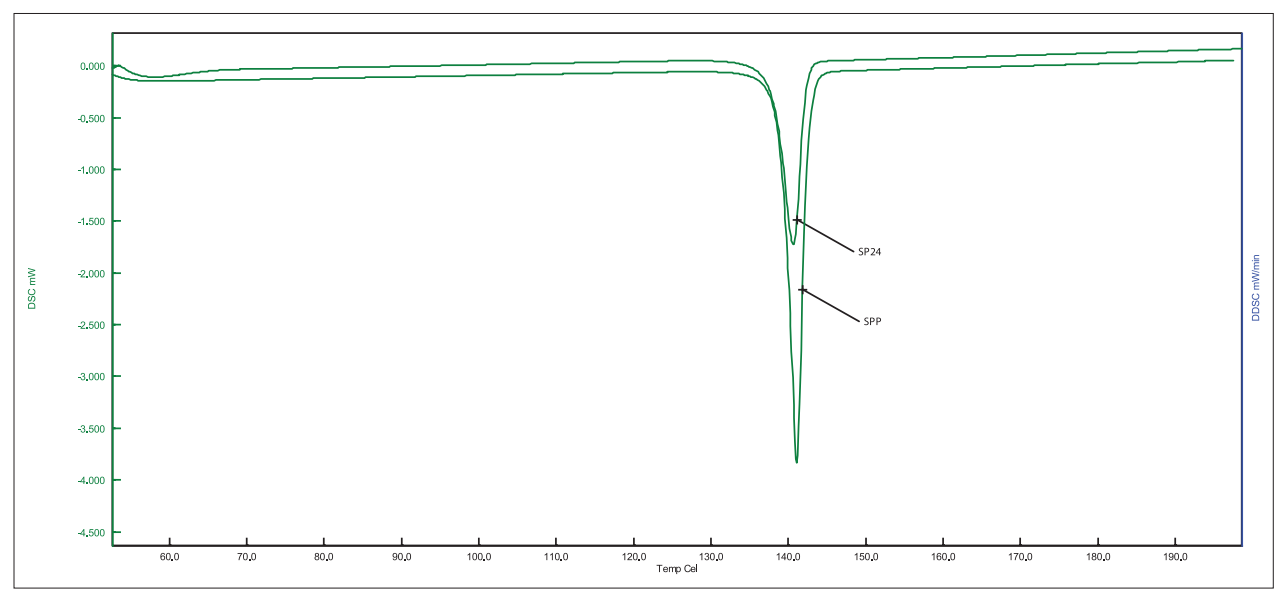

Fig. 13: Differential scanning calorimeter of pure drug and batch B20

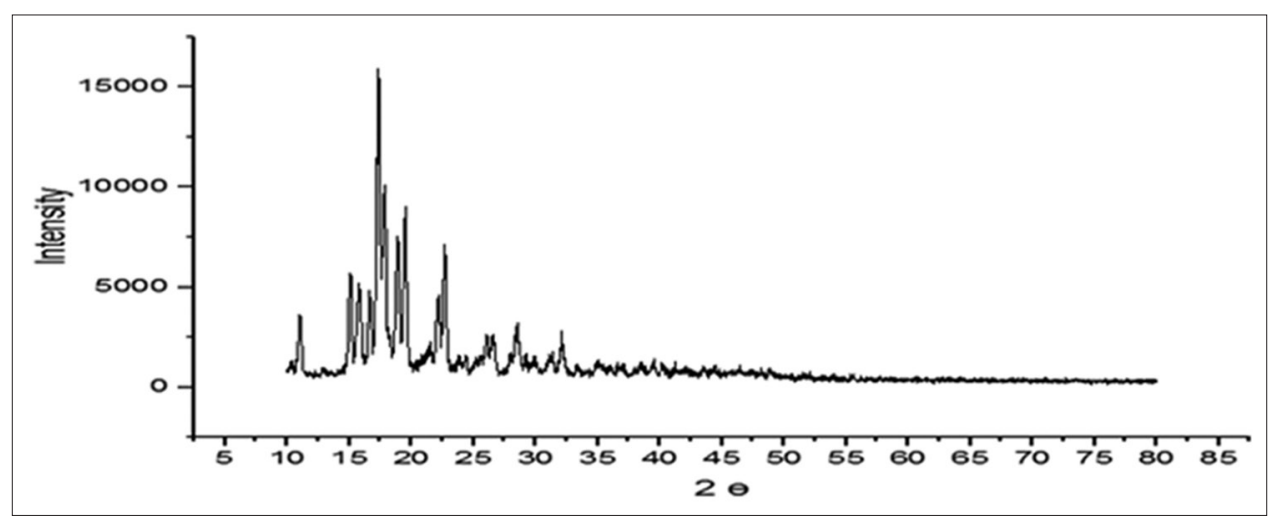

Fig. 14: Powder X-ray diffraction pattern of simvastatin

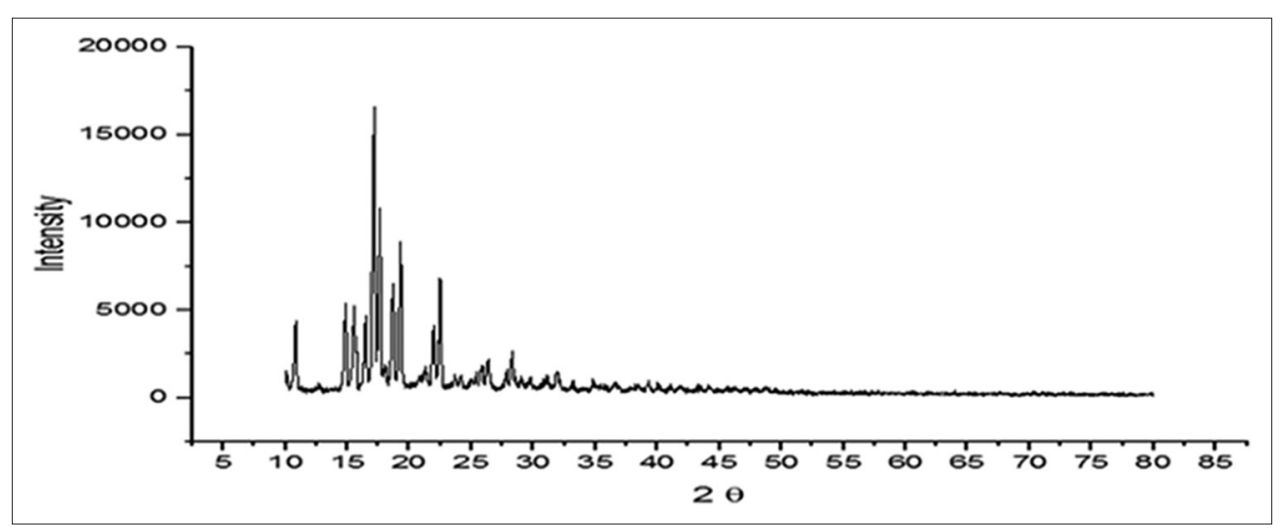

Fig. 15: Powder X-ray diffraction pattern of batch B20

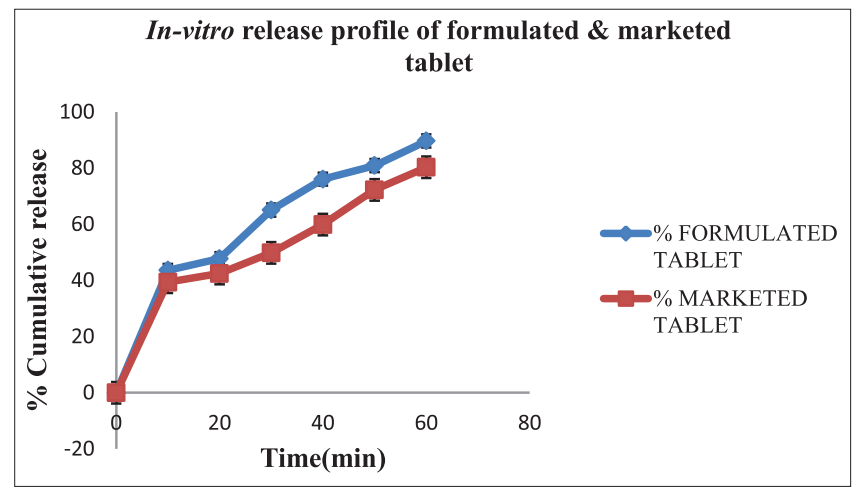

Fig. 16: Comparison of in-vitro release profile of formulated and marketed tablet. Mean \pm standard error $(n=3)$

\section{ACKNOWLEDGMENT}

Authors are thankful to Watson India Ambernath and Cipla Pvt. Ltd. Pune, for providing gift sample of simvastatin drug.

\section{REFERENCES}

1. Chauhan N, Satapara V, Sorathiya K, Parmar K, Raval M, Patel P. Spherical crystallization: An aspect to increase the pysicochemical properties of drugs, Int J Pharm Innov 2012;2(4):37-47.

2. Kumar S, Chawla G, Bansal AK. Spherical crystallization of mebendazole to improve processability. Pharm Dev Technol 2008;13(6):559-68.

3. Ambike AA, Mahadik KR, Paradkar A. Spray-dried amorphous solid dispersions of simvastatin, a low tg drug: In vitro and in vivo evaluations. Pharm Res 2005;22(6):990-8.

4. Cheng H, Sutton S, Pipikin J. Evaluation of sustained/controlledrelease dosage forms of 3-hydroxy-3-methylglutaryl coenzyme a 
(HMG-coA) reductase inhibitor in dogs and humans. Pharm Res 1993;10(11):683-7.

5. Mcclelland C, Stubbs R, Fix J, Pogany S, Zentner G. Enhancement of 3- hydroxy-3- methylglutaryl-coenzyme a (HMGcoA) reductase inhibitor efficacy through administration of a controlled-porosity osmotic pump dosage form. Pharm Res 1991;8(7):873-6.

6. Dixit RP, Nagarsenker MS. In vitro and in vivo advantage of celecoxib surface solid dispersion and dosage form development. Int J Pharm Sci 2007:69(3):370-7.

7. Katta J, Rasmuson AC. Spherical crystallization of benzoic acid. Int J Pharm 2008;348(1-2):61-9.

8. Gupta VR. Formulation and evaluation of directly compressible agglomerates of Celecoxib. Int $J$ Pharm Sci Nanotechnol 2011;3(4):1193-204.

9. Nandgude TD, Bhise KS, Gupta VB. Characterization of hydrochloride and tannate salts of diphenhydramine. Indian $J$ Pharm Sci 2008;70(4):483-7.

10. Gohle MC, Parikh RK, Shen H. Improvement in flowability and compressibility of Ampicilline Trihydrate by spherical crystallization. Indian J Pharm Sci 2003;6(13):634-7.
11. Yadav VB, Yadav AV. Designing of pharmaceuticals to improve physicochemical properties by spherical crystallization technique. J Pharm Res 2008;1(2):105-12.

12. Ueda M, Nakamura Y, Makita H, Imasato Y, Kawashima Y.Particle design of enoxacin by spherical crystallization technique II, Characteristics of agglomerated crystals. Chem Pharm Bull 1991;39(5):1277-81.

13. Thenge RR. Crystal modification of aceclofenac by spherical crystallization to improve solubility dissolution rate and micromeritic properties. J Pharm Res 2011;5(2):974-7.

14. Fatima S, Jamil S. Effect of surfactant on dissolution of simvastatin tablets; comparison with usp. W J Pharm Pharm Sci 2014;3(3):142-50.

15. Srinu R, Krishna M, Rao KV. Formulation and evaluation of fast dissolving tablets of simvastatin using novelco - Processed superdisintegrants. Sch Acad J Pharm 2003;2(4):340-53.

16. Rajaiya P, Mishra RK, Nandgude TD, Poddar S. Solubility and dissolution enhancement of albendazole by spherical crystallization. Asian J Biomed Pharm Sci 2016;6(52):09-14.

17. Mishra RK, Nandgude TD. Spherical crystallization for solubility and dissolution enhancement of meloxicam by neutralization method. Invent Impact Pharm Process Dev 2016;2016(2):74-81. 